\title{
The role of the frontal ganglion in the control of protein metabolism in Locusta migratoria
}

\author{
Cedric Gillot \\ Department of Zoology, University of Nottingham, Nottingham, England
}

\begin{abstract}
KURZFASSUNG: Die Bedeutung des Frontalganglions für die Kontrolle des Proteinstoffwechsels bei Locusta migratoria. Am dritten Nymphenstadium von Locusta migratoria konnten Clarke \& LANGLey (1963a) zeigen, daß die Entfernung des Frontalganglions eine völlige Einstellung des Körperwachstums zur Folge hat. Elektrophorese des Blutes operierter Tiere läßt eine starke permanente Abnahme des Proteingehaltes erkennen. Gleichzeitig kommt es za einer allgemeinen Verringerung des RNS-Gehaltes der Gewebe. Diese ist besonders augenfällig in den aktivsten Geweben, wie etwa der Epidermis und dem Mitteldarmepithel. Weiterhin ergaben papierchromatographische Untersuchungen, daß - im Gegensatz zu der bei Hungertieren angetroffenen Situation - eine Abnahme der Aminosäurekonzentration des Blutes erfolgt, welche ihrerseits wiederum zu einem Zusammenbruch des Wasserhaushaltes führt. Noch nicht abgeschlossene Untersuchungen über die Mitteldarmproteasen deuten auf eine ungenügende Synthese dieser Enzyme in den Epithelzellen der operierten Tiere hin. Es wird eine allgemeine Kontrolle der Proteinsynthese durch das neurosekretorische System postuliert und angenommen, daß dieses System wiederum durch sensorische Impulse kontrolliert wird, welche von den pharyngealen Dehnungsrezeptoren über das Frontalganglion zum Gehirn gelangen.
\end{abstract}

\section{INTRODUCTION}

Over the past few years work in our laboratory has centred around growth and metabolism in insects, in relation to environmental conditions. Out of this work emerged the possibility that the frontal ganglion was involved in the control of 'protein metabolism' (and therefore growth) in a continously growing insect. The manner in which this control was effected was not, however, clear although the preliminary studies on the blood proteins indicated that these were involved. My first object, therefore, was to make a closer examination of any changes in blood protein concentration which occurred throughout an instar.

\section{METHODS AND RESULTS}

Throughout this investigation, third instar nymphs of Locusta migratoria were used. At this stage sex differences are small and therefore no distinction was made. The method of culture, the operative technique and the post-operational treatment were all as given by CLARKE \& LANGLEY (1963a, b). 
Cellulose-acetate paper electrophoresis was carried out under the following conditions: potential difference 160 volts, current 0.3 to $0.5 \mathrm{amps} / \mathrm{cm}$., running time 7 hours at room temperature. The dried strips were then stained in light green $(0.2 \%$ in $5 \%$ acetic acid) and, after clearing, scanned with a densiometer, to reveal the following information (Fig. 1). The number of proteins separating out was usually 4 but

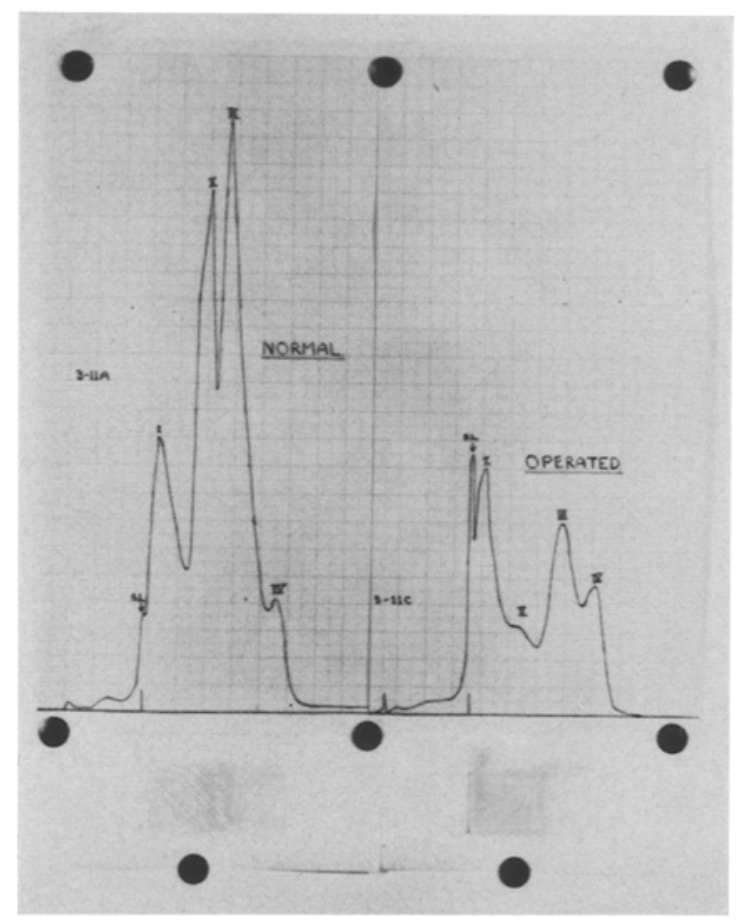

Fig. 1: The blood protein level in normal and operated animals. The differences are most clearly seen in bands 2 and 3

occasionally up to 7 could be distinguished. Although in normal animals the concentration of the various protein components varied, there was a gradual, general increase towards the end of the instar. The protein level in the blood of operated animals, however, was initially low and remained thus throughout the life of the animal. This effect is particularly noticeable in bands 2 and 3.

WIGGLESWORTH (1957) has shown that the nutritional state within an insect is clearly reflected when a histochemical study of the nucleic acids within various tissues is carried out. Accordingly the head and midgut from the animals previously used in the electrophoretic studies were fixed and stained for nucleic acids using BRACHET's (1953) method. The head was used since it facilitates examination of a variety of tissues and the midgut since it is a site of very active protein synthesis. The low RNA content was generally indicative of a lack of protein synthesis within the cells of operated animals. The most noticeable effects were these: - 
(a) The epidermal and gut-epithelial cells were smaller in operated animals.

(b) The nuclei were smaller but the DNA concentration appeared higher (probably because the amount of stainable material remained the same).

(c) The nucleoli, which in normal animals were very prominent, were either small or absent.

(d) The cytoplasmic RNA concentration was much less in operated animals. This was particularly noticeable in the more active tissues, i. e. the epidermis and the gutepithelium (Fig. 3).

(e) Finally, the fat-body, which in normal animals is quite extensive towards the end of the instar, was rudimentary and invisible.

Insect blood is unique in that it possesses a very high amino-acid concentration. One of the functions of the latter is doubtless to provide material for protein synthesis (HILI 1962), and an investigation of it was therefore considered worthwhile. A semi-

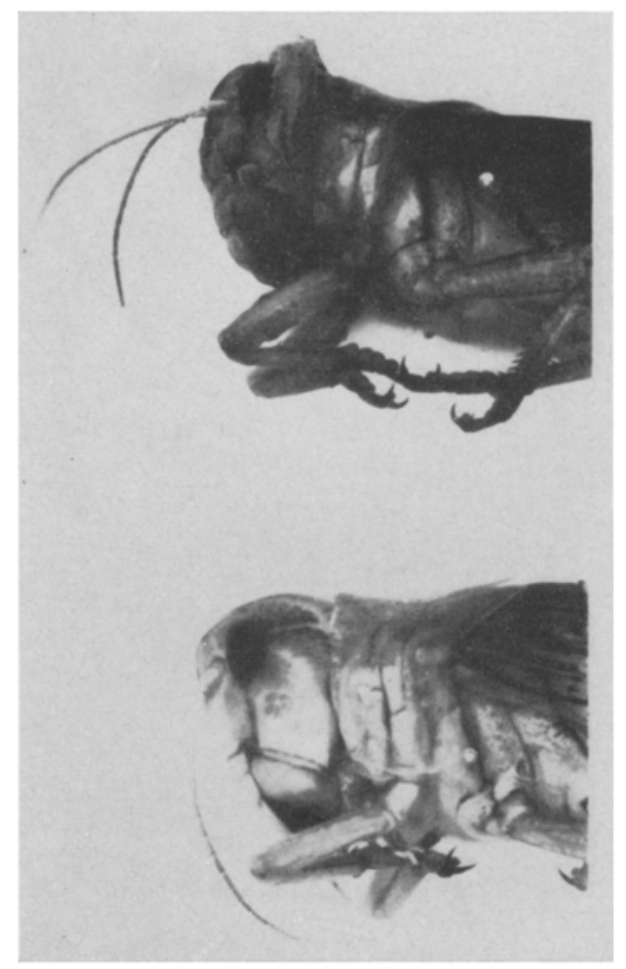

Fig. 2: The accumulation of dust on the head of an operated animal (upper photograph) due to the exudation of moisture through the cervical membrane. (This is shown by kind permission of Dr. Clarke)

quantitative method of two dimensional paper chromatography was used, with $\mathrm{n}$-butanol 4 : acetic acid $1:$ water $5(\mathrm{v} / \mathrm{v})$ and phenol $500 \mathrm{~g}$. : water $125 \mathrm{ml}$. as solvents. The chromatograms were run on Whatman No. 1 paper for 16 hours in each direction at room temperature. After drying and staining $10.5 \%$ ninhydrin in anhydrous ace- 


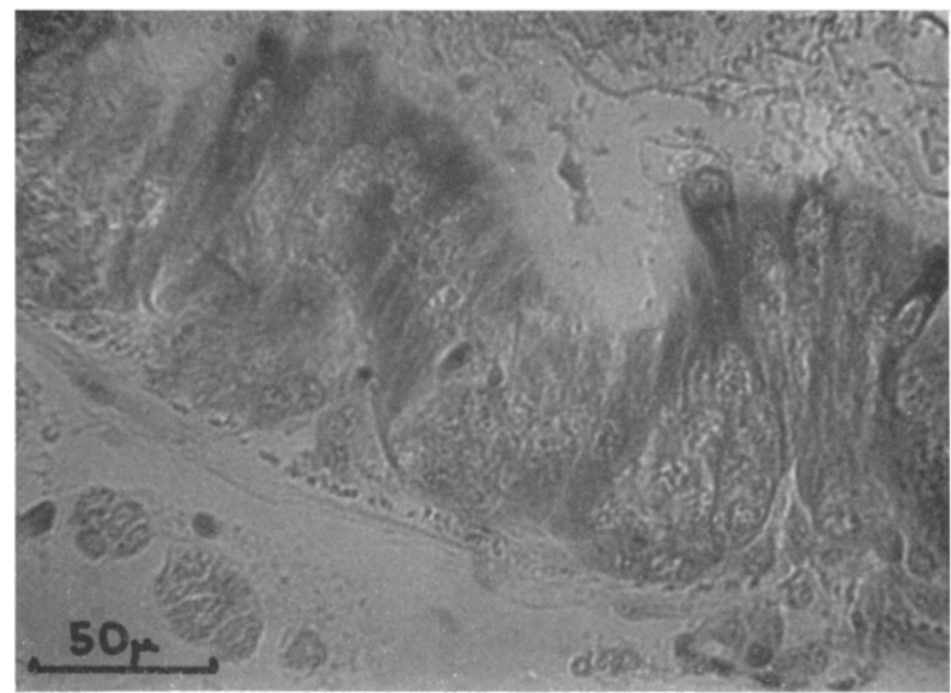

Fig. 3a

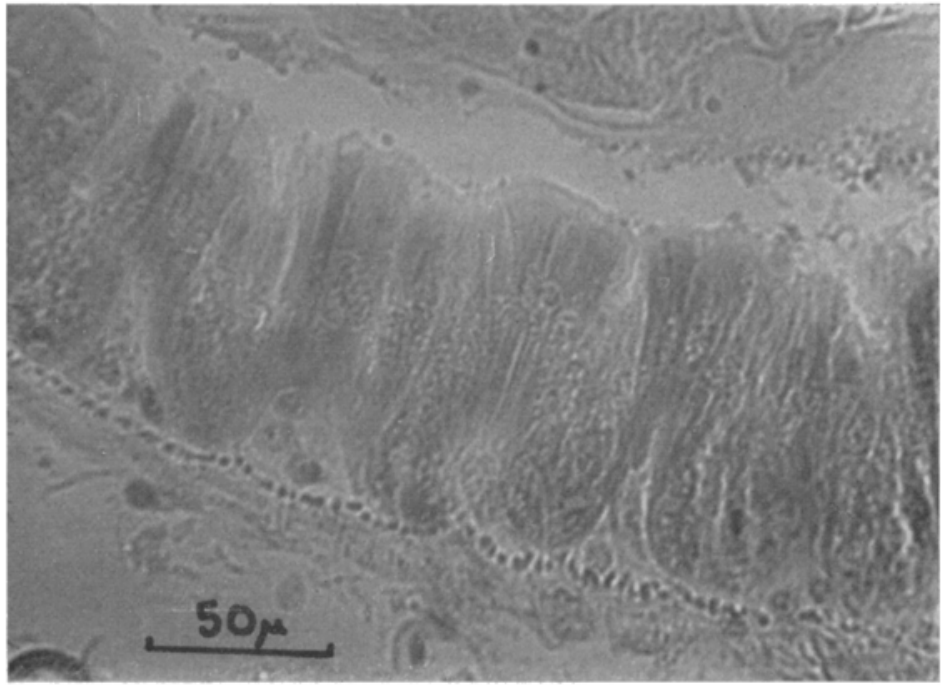

Fig. 3b

Fig. 3: Transverse sections through the midgut of (a) normal and (b) operated animals, stained with methyl green and pyronin. The abundant RNA in the mature cells of the normal animal shows as the darkly stained distal areas. This is not seen in $(b)$

tone), the spots were eluted in $75 \%$ ethanol and their optical density measured. The advantage of this over an estimation of 'total' amino-acids was that changes in individual amino-acids could be detected from which the net change in concentration could be calculated. The results for normal animals compared favourably with those ob- 


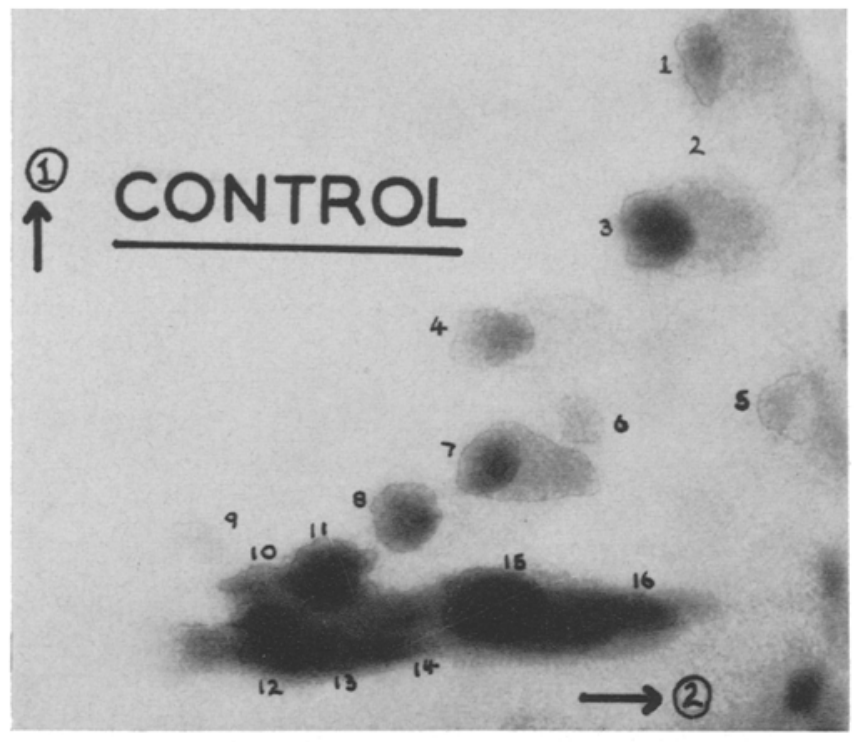

Fig. $4 \mathrm{a}$

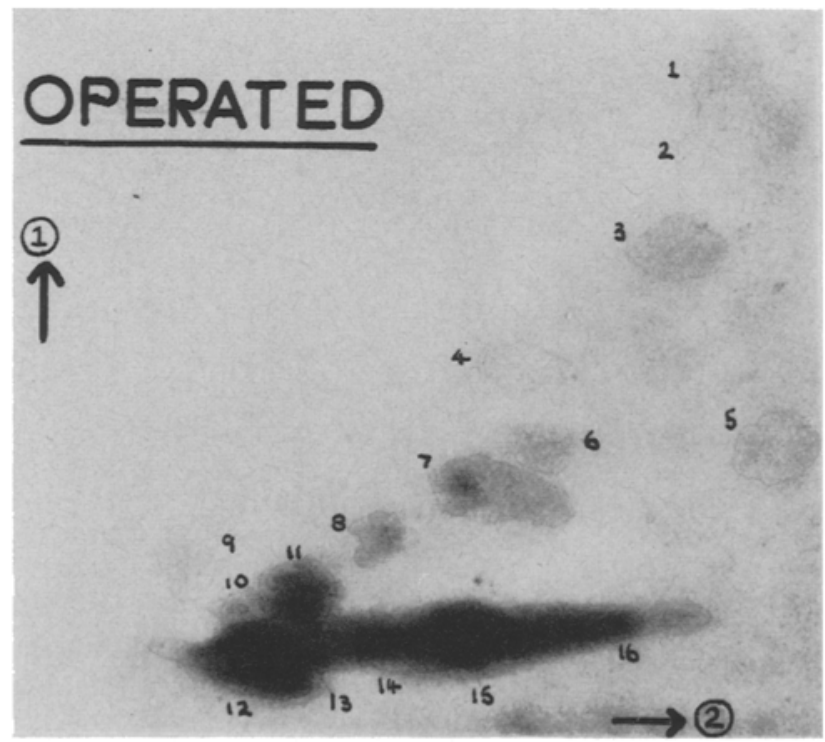

Fig. $4 \mathrm{~b}$

Fig. 4: Chromatograms of the amino-acids in the blood of (a) control and (b) operated animals. The differences in amount can clearly be seen in the farthest travelled components

tained by other workers (DUCHATEAU et al. 1952), but in operated animals the picture was quite different (Fig. 4). Thus while some amino-acids disappeared almost completely from the blood of operated animals, others were present in slightly higher 
concentrations than in normal animals. The total amino-acid concentration, however, fell markedly until it was only about $60 \%$ of that in normal animals.

The work of THOMsen \& Møller $(1959,1963)$ together with the results given above suggested that an estimation of the midgut protease activity might prove profitable and although this work is not yet completed the preliminary results are given below. Using the titrimetric method of DAY \& PownING (1949) the enzyme activity of the midgut epithelium and the midgut contents was measured separately to assess whether release of enzyme had been affected. In both normal and operated animals the ratio,

$$
\frac{\text { enzyme activity of contents }}{\text { enzyme activity of gut-wall, }}
$$

appears to be the same, thus indicating that enzyme release was not inhibited. The total activity, however, is much lower in operated than in normal animals. The number of animals used in the above experiments is given in Table 1.

Table 1

Number of animals used in the experiments described

\begin{tabular}{|lc|ccc|cc|}
\hline Experiment & Total & \multicolumn{4}{|c|}{ Experimental Condition } \\
number & Normal & $\begin{array}{c}\text { Operated } \\
\text { Control }\end{array}$ & Operated & Starved \\
Completely on & $\begin{array}{c}\text { Sucrose } \\
\text { Solution }\end{array}$ \\
\hline $\begin{array}{l}\text { Electrophoresis } \\
\text { and Histochemistry }\end{array}$ & 95 & 23 & 23 & 31 & 6 & $\left.12^{*}\right)$ \\
$\begin{array}{l}\text { Amino-acid*; } \\
\text { Determination } \\
\text { Enzyme }\end{array}$ & 60 & - & 24 & 36 & - & - \\
\hline Estimation & 64 & 27 & 13 & 14 & 10 & - \\
\hline
\end{tabular}

*) Two of these animals were eventually provided with grass to ched that blood protein and cytoplasmic ribonucleic acid did rise after feeding. 2 chromatograms could be run in the same tank at any one time. Hence only operated and control animals have been used.

\section{DISCUSSION}

The above results provide clear evidence that the frontal ganglion plays a vital part in controlling protein synthesis within the growing locust. An interesting comparison can now be drawn between operated and starved animals. Thus in both, the blood protein level, the cytoplasmic RNA level, and the protease level are all below that of the normal animal. On the other hand whilst the amino-acid concentration of the blood falls after operation, it remains at the same level in starved locusts. Further, in the latter, all these abnormalities can be corrected within hours by providing food 
but this is not possible in operated animals, which in any case are always well supplied with food. It seems therefore that through removal of the frontal ganglion, we have stopped the ability to use the protein available in the food.

The question arises as to whether removal of this ganglion, mediated through a lack of neurosecretory material, has a general effect on the protein synthesis of all tissues or a specific effect on the protein (enzyme) synthesis of the midgut epithelium. The histochemical studies suggest that a general effect is more likely, and this is in agreement with the work on proteases, since as the enzyme activity in the gut lumen does not fall to zero, a few amino-acids are presumably still being made available, and growth should still occur (but at a reduced rate). As it is, growth ceases completely after removal of the frontal ganglion.

It is interesting that the amino-acid level in the blood of operated animals falls to about $60 \%$ of its value in normal animals, since it is known that another function of the blood amino-acids is water retention within the animal because of the high osmotic pressure which they create. This result can therefore be correlated with CLARKE and LANGLEY's observation that in operated animals drops of moisture accumulated in the region of the intersegmental membranes (Fig. 2) (particularly the 'neck' membrane) suggesting that, in fact, the water-balance mechanism had broken down. Other workers (for example, Nunez 1956, and Altmann 1956) have shown that injection of neurosecretory material promotes water retention in insects. In normal animals there is a continual wearing away of the intersegmental membranes as they rub against each other. They are, therefore, always being replaced by new material synthesised in the epidermal cells. Hence another possible explanation for this water loss in operated animals is that it is due to the non-replacement of the proteinaceous components of the cuticle and the consequent increased permeability of the membranes.

The lack of fat-body in operated animals noted both in sections and upon dissection is of interest since SHIGEMATsu (1958), working on the silkworm, provided evidence that this tissue was a major site for the synthesis of blood protein. The absence of a fat-body suggests furthermore that we must have interfered with fat metabolism because in the normal growing animal this tissue also acts as a site for fat storage. Carbohydrate metabolism is, however, apparently unaffected as indicated by the constant weight and normal activity of operated animals. In this connection it is interesting to note that animals fed only on a strong solution of sucrose maintain a constant body weight and do not moult, for a period of over 200 hours.

\section{CONCLUSION}

The results presented above provide strong evidence for the involvement of the frontal ganglion in the control of protein synthesis in a continuously growing animal. Information concerning the intake of food into the gur, passes to the brain via the ganglion and there causes the synthesis and release of neurosecretory material. This stimulates the synthesis of RNA within the nucleus (KARLSON 1960) and, in turn, protein within the cytoplasm. 


\section{SUMMARY}

1. After removal of the frontal ganglion, there is an immediate permanent decrease in the blood protein level.

2. The cytoplasmic RNA concentration, the blood amino-acid level and the midgut protease level, also decrease after this operation.

3. These effects cannot be reversed by feeding as is the case in starved animals.

4. The above results provide clear evidence that the frontal ganglion plays a vital part in controlling protein synthesis in the growing locust.

\section{ACKNOWLEDGMEN'T'}

I would like to record my sincere thanks to Dr. K. U. CLARKE for his continued advice and encouragement in this work.

\section{LITERATURE CITED}

Altmann, G., 1956. Die Regulation des Wasserhaushaltes der Honigbiene. Insectes Sociaux, Paris, 3, 33-40.

Brachet, J., 1953. The use of basic dyes and ribonuclease for the cytochemical detection of ribonucleic acid. Quart. J. micr. Sci. 94, 1-10.

Clarke, K. U. \& LANGLeY, P. A., 1963a. Studies on the initiation of growth and moulting in Locusta migratoria migratorioides $\mathrm{R}$. \& F. I. The time and nature of the initiating stimulus. J. Ins. Pbysiol. 9, 287-292.

- 1963b. Studies on the initiation of growth and moulting in Locusta migratoria migratorioides R. \& F. II. The role of the stomatogastric nervous system. J. Ins. Physiol. 9, 363-373.

DaY, M. F. \& Powning, R. F., 1949. A study of the processes of digestion in certain insects. Aust. J. sci. Res. (B) 2, 175-215.

Duchateau, G., Florkin, M. \& Sarlet, H., 1952. Sur les acides aminés, libres ou combinés sous forme non protéinique du plasma de divers insectes. Arch. int. Pbysiol. 60, 539-540.

IHILL, L., 1962. Neurosecretory control of haemolymph protein concentration during ovarian development in the desert locust. J. Ins. Physiol. 8, 609-619.

Karlson, P., 1962. On the chemistry and mode of action of insect hormones. Gen. comp. Endocrin. Supplement 1, 1-7.

NunEZ, J. A., 1956. Untersuchungen über die Regelung des Wasserhaushaltes bei Anisotarsis cupripennis. Z. vergl. Physiol. 38, 341-354.

Shigmatsu, H., 1958. Synthesis of blood protein by the fat body in the silkworm, Bombyx mori L. Nature, Lond. 182, 880-882.

Thomsen, E. \&c Molize, I., 1959. Neurosecretion and intestinal proteinase activity in an insect, Callipbora erythrocephala Merg. Nature, Lond. 183, 1401-1402.

- 1963. Influence of neurosecretory cells and of corpus allatum on intestinal protease activity in the adult Callipbora erythrocephala Meig. J. exp. Biol, 40, 301-321.

WIGGLESWORTH, V. B., 1957. The action of growth hormones in insects. Symp. Soc. exp. Biol. 11, 204-227. 


\section{Discussion following the paper by GLLOTT}

WIESER: In some animals it has been shown that a long day period induces the production of neurosecretory material in the brain. Could it be that in Locusta a change in the light/dark period might compensate for the severance of the frontal ganglion and stimulate growth despite the absence of the ganglion?

GILLOTT: Both normal and operated animals are maintained under conditions of a 12 hour dark/12 hour light photoperiod. We have not carried out any experiments to examine whether the light has an effect on release of neurosecretory material, but the fact that material accumulates in the nervi corporis cardiaci after operation, even though the animals receive 12 hour light daily, would appear to rule out this possibility. 